\title{
APPROACHES TO POST-MINING LAND RECLAMATION IN POLISH OPEN-CAST LIGNITE MINING
}

\author{
Zbigniew KASZTELEWICZ1 \\ AGH University of Science and Technology, \\ Faculty of Mining and Geoengineering, Krakow, Poland
}

\begin{abstract}
The paper presents the situation regarding the reclamation of post-mining land in the case of particular lignite mines in Poland until 2012 against the background of the whole opencast mining. It discusses the process of land purchase for mining operations and its sales after reclamation. It presents the achievements of mines in the reclamation and regeneration of post-mining land as a result of which-after development processes carried out according to European standards-it now serves the inhabitants as a recreational area that increases the attractiveness of the regions.
\end{abstract}

Keywords: lignite open-cast mining, reclamation, revitalization, land management

\section{INTRODUCTION}

The way how land is used in every case leaves a permanent mark and has an impact on the character and range of changes of its natural characteristics. Industrial interference into the soil environment causes purposeful but also unintentional effects; it results in both positive and negative changes. Since the beginning of history man has aimed at taking the advantage of the natural resources and along with the development of specialized tools he has tried to reach deeper and deeper into the earth. Opencast mining is the simplest method of gaining the resources. This method is applied in Poland in the mining of around 40 different useful minerals such as sand, gravel, clays, building and

\footnotetext{
${ }^{1}$ Corresponding author: AGH University of Science and Technology, Faculty of Mining and Geoengineering, Al. Mickiewicza 30, 30-059 Kraków, Poland; e-mail: kasztel@agh.edu.pl, tel. +48126172105
} 
road stone, limestone, marl, sulfur and lignite. The reclamation of post-mining land is the stage of mining that on one hand compensates the disadvantageous results of mining activities but on the other it contributes to the creation of some new, often more attractive development of land. The range and scale of the reclamation processes that are carried out in Poland are equivalent to the position of opencast mining in the Polish economy. In Poland there are over 5000 active mines that operate on over 26000 hectares of land and mine almost $300 \mathrm{mln} \mathrm{Mg}$ of various useful minerals and over $250 \mathrm{mln} \mathrm{m}^{3}$ of overburden a year. As you can see, it is a substantial share and - according to the forecasts for the opencast mining industry - it will even increase.

It is estimated that in 2015 the maximum production of crushed-stone aggregate may reach $350(\mathrm{mln} \mathrm{Mg}) \cdot \mathrm{y}^{-1}$, while the production of electric energy may double in the next 30-40 years resulting in the growth of the lignite mining. Table 1 presents the condition of the area covered by mining operations in Poland, divided by total mining and opencast mining [3].

Table 1. The condition of the area covered by mining operations in Poland, by the whole mining and opencast mining, including the mining of rock minerals and lignite [3]

\begin{tabular}{|l|c|c|c|c|c|c|}
\hline Year & 1992 & 1995 & 2000 & 2005 & 2008 & 2011 \\
\hline Mining as such [ha] & 54200.9 & 52693.6 & 44991.0 & 39299.6 & 39203.0 & 38065.1 \\
\hline Rock minerals [ha] & 16504.1 & 15804.4 & 14860.0 & 12231.1 & 11885.1 & 11650.1 \\
\hline Lignite [ha] & 15887.5 & 16229.5 & 15612.0 & 16174.3 & 17317.5 & 16601.6 \\
\hline Opencast mining [ha] & 32391.6 & 32033.9 & 30472.0 & 28405.4 & 29202.6 & 28251.7 \\
\hline
\end{tabular}

The figures in the table show that there is a constant decrease in the area used by particular mining branches, which indicates that care is taken in the field of reclamation and that unnecessary land is sold systematically.

Among the area that is returned for further development, the land given back to forestry accounts for approx. $60 \%$, for agricultural reclamation - about $20 \%$ and for hydrological reclamation - about $10 \%$. The remaining $10 \%$ accounts for other type of reclamation, including special approach that considers various possibilities: recreational areas, housing areas, parks, playgrounds, etc [3].

In the opinion of post-mining land reclamation specialists the process of reclamation should not be constrained to making the wasteland "green". One should aim at an effective and multifunctional development of land, having in mind the basic rule of sustainable growth. Such attitude will enable us to obtain land that is comparably or insignificantly less productive than it was before taking industrial operations. There have even been cases where after the reclamation the soil quality class happened to be better then before taking it by 
the mining industry (e.g. in the areas of the Adamów and Konin lignite mines and the Szczakowa filling sand mine) [4].

\section{HISTORICAL OUTLINE OF LEGAL REGULATIONS AS REGARDS RECLAMATION}

Over years or even centuries legal regulations regarding reclamation of postmining land have been undergoing numerous changes. The pride of the Polish mining legislation and one of the oldest acts (Ordunek Górny) of 1528 passed by one of the last members of Piast dynasty in Opole provided for some kind of 'reclamation procedure'. The act introduced financial penalty in case of mining damage. Closer to contemporary times the Decree on Mining Law of the President of the Republic of 29 November 1930 should be mentioned. The decree that functioned as an act did not use the notion reclamation. However, it provided for wide compensation to everybody who suffered due to activities conducted on the so called mining fields. Only the Decree on Mining Law of 6 May 1953 provided for the post-mining land reclamation by means of a separate regulation on the subject. The 1960s and 1970s are the period of the development of industry, which at the same time returned increasingly vast areas that required reclamation. The lignite and sulfur mining industries were a kind of pioneers then, as the reclamation was conducted on highly devastated and downgraded grounds. It could be said that at the end of 1970 and the beginning of 1980s the Polish school of reclamation was born. The Act on Mining and Geological Law of 4 February 1994 neglected the need to introduce reclamation in a special way. It identified reclamation as a process of repairing damage. However, life showed that there is a necessity to pass a separate regulation. That is the reason why in 2001 both article 80 and 109 were changed. The change, introduced by the Act of 27 July 2001 on the Change of the Act on Geological and Mining Law regulated separately the process of reclamation after the liquidation of a mine from the reclamation forced by mining damage. And that law is still applicable.

\section{LAND MANAGEMENT AND POST-MINING RECLAMATION IN THE LIGNITE SECTOR}

Lignite mining has been systemically continuing to reclaim and develop "recovered" areas in time with the movement of the exploitation front. The mines are not behindhand with the reclamation of the exploited areas. The work is done on high European level that ensures the use of land in agriculture, forestry and other activities, recreational ones including. Tables 2 and 3 present 
data regarding the management of land in different mines; figure 1 shows the amount and percentage share of the land purchase by lignite mines since the beginning of their operations.

Table 2. The amount of land purchased and owned and the amount of ground sold between the start of operations till the end of 2012 [the authors' research]

\begin{tabular}{|l|c|c|c|c|}
\hline Mine & $\begin{array}{c}\text { Land purchase } \\
\text { since the } \\
\text { beginning of } \\
\text { operations }\end{array}$ & $\begin{array}{c}\text { Land sold since } \\
\text { the beginning } \\
\text { of operations }\end{array}$ & $\begin{array}{c}\text { Land owned } \\
\text { at the end of } \\
2010\end{array}$ & $\begin{array}{c}\text { Land } \\
\text { purchased per } \\
1 \text { mln Mg of } \\
\text { output since } \\
\text { the beginning } \\
\text { of operations }\end{array}$ \\
\cline { 2 - 5 }$\left[\begin{array}{c}\left.\text { [ha] }[\mathrm{mln} \mathrm{Mg})^{-1}\right] \\
\hline \text { Adamów }\end{array}\right.$ & 6168 & 3452 & 2716 & 31.65 \\
\hline Bełchatów & 10907 & 3866 & 7041 & 11.37 \\
\hline Konin & 13882 & 8321 & 5560 & 24.26 \\
\hline Turów & 5289 & 1718 & 3580 & 6.00 \\
\hline Total & 36246 & 17357 & 18897 & 13.90 \\
\hline
\end{tabular}

Table 3. Sales and transference of land by mines in 2012 [the authors' research]

\begin{tabular}{|l|l|c|c|c|c|c|}
\hline \multicolumn{2}{|c|}{ Mine } & Adamów & Bełchatów & Konin & Turów & Total \\
\hline $\begin{array}{l}\text { Transferred - } \\
\text { sold }\end{array}$ & Total & 3452 & 3866 & 8321 & 1718 & 17357 \\
\hline \multirow{2}{*}{ including } & unchanged & 260 & 2292 & 2334 & 267 & 5153 \\
\cline { 2 - 7 } & reclaimed & 3192 & 1574 & 5988 & 1451 & 12205 \\
\hline $\begin{array}{l}\text { Ownership at the } \\
\text { end of 2012 }\end{array}$ & 2716 & 7041 & 5560 & 3580 & 18897 \\
\hline
\end{tabular}

The Konin lignite mine, which has done $50 \%$ of the whole industry's reclamation work, is the leader as regards the surface area. The Adamów mine is the second, and then there are the Bełchatów and Turów mines. Figure 2 shows the amount of land that was returned after the reclamation in particular mines from the beginning of their operations till 2010. The Konin and Adamów mines are at the top mainly due to the fact that they are typical open-cast mines with several workings and they mine small deposits of lignite. As a result new opencasts "help" in the reclamation of the old ones as the overburden and waters that come from them may be directed to the ones that are being liquidated. Figure 3 presents a quantitative range of the necessary sales-purchase of land in hectares and the range per one mln of the coal mined [1].

The biggest number of hectares per one $\mathrm{Mg}$ of lignite mined can be observed in the Adamów mine, and the least in the Turów mine. 


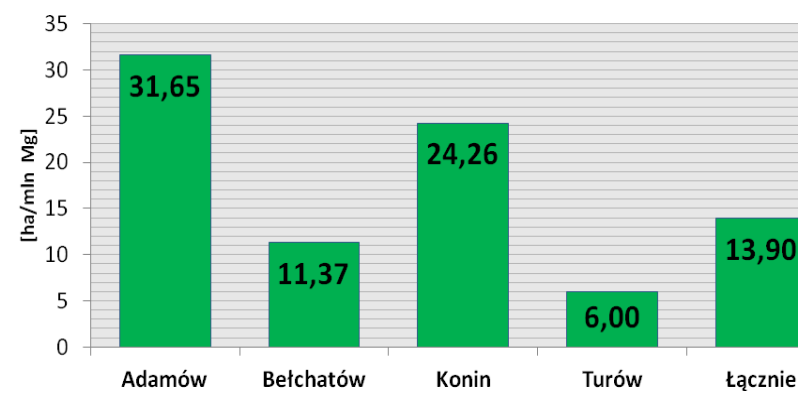

Fig. 1. Amount of land purchased per $1 \mathrm{mln} \mathrm{Mg}$ of lignite mined from the beginning of operations till 2012 [the author's research]

\section{EXAMPLES OF POST-MINING LAND RECLAMATION IN PARTICULAR APPROACHES}

The Turów and Bełchatów mines reclaim the land mainly but not only for the forestry. However, the structure of the reclamation in the case of the Adamów and Konin mines that have many workings is more varied. Table 4 presents the percentage share of particular approaches to reclamation in Polish lignite mines.

Table 4. Percentage share of particular directions of reclamation in Polish lignite mines

\begin{tabular}{|l|c|c|c|c|c|}
\hline \multirow{2}{*}{ Mine } & \multicolumn{5}{c|}{ Approach to reclamation } \\
\cline { 2 - 6 } & agricultural & forestry & hydrological & special & recreational \\
\hline Konin & $50 \%$ & $31 \%$ & $8 \%$ & $9 \%$ & $2 \%$ \\
\hline Adamów & $59 \%$ & $17 \%$ & $24 \%$ & $1 \%$ & - \\
\hline Bełchatów & - & $95 \%$ & - & $4 \%$ & $1 \%$ \\
\hline Turów & - & $96 \%$ & - & $4 \%$ & - \\
\hline
\end{tabular}

\subsection{Agricultural approach}

The agricultural approach has been chosen mainly by the Adamów and Konin mines. The other two lignite mines after several attempt have given up this direction of reclamation of post-mining land. Thanks to the reclamation processes that are carried out in such areas the ground that was placed there in the course of dumping gains the status of agricultural land and may be sold by tender. The land that was taken for mining operations had low soil quality (class $\mathrm{V}$ and VI) and after complicated reclamation and agrotechnical treatments was upgraded to class III and IV. At present on the newly created agricultural areas maze, lucerne, corn, sunflowers and beetroots are grown; what is more pastures are made. So far the Adamów lignite mine has reclaimed for agricultural 
purposes 2185 ha, for forestry 928 ha, and as regards water and special approaches - 514 ha (including 165 ha of the Przykona water reservoir). In the case of the Konin mine the figures are significantly higher which is due to a much wider scale of operations. Till the end of 2010 the agricultural approach accounted for 3909 ha, forestry approach - 2402 ha, hydrological approach - 596 ha, recreational approach - $160 \mathrm{ha}$, and other approaches - 701 ha (it is mainly for the waste storage dumps), all of which amounts to impressive $7768 \mathrm{ha}$.

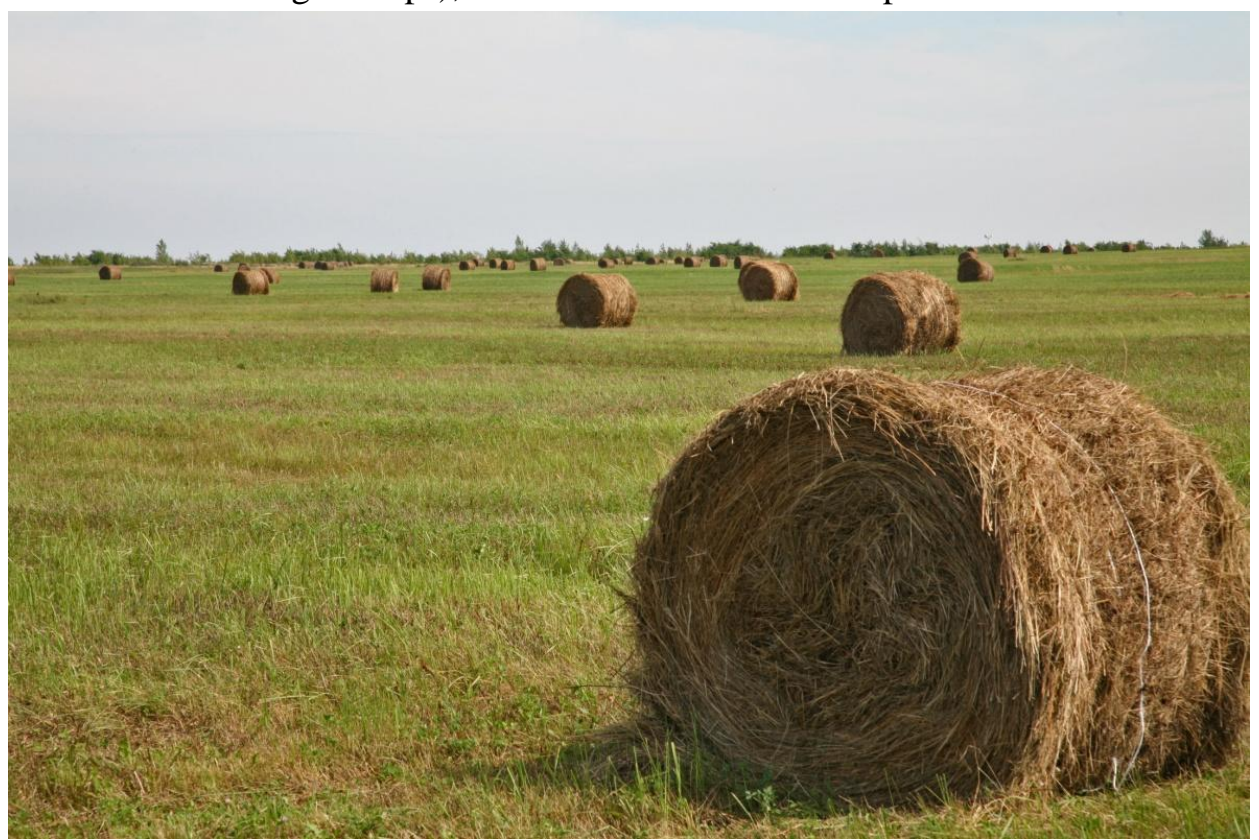

Fig. 2. Lucerne crops on the dumping ground of the Konin mine Lubstów open-pit [phot. by Kasztelowicz]

\subsection{Forestry approach}

It is the most common approach when the surface area of the post-mining land being reclaimed is to be considered. The approach is applied by all lignite mines in Poland but the most spectacular examples are provided by the big ones - the Bełchatów and Turowa lignite mines. They carried out forestry reclamation mainly in their external dumping sites. The two areas covered over 3600 ha. Their reclamation was a complicated process and it was carried out successively for years simultaneously to the mining and dumping operations. A surface which was not much smaller (over 3300 ha) was developed with the same approach by the Adamów and Konin mines [4]. 


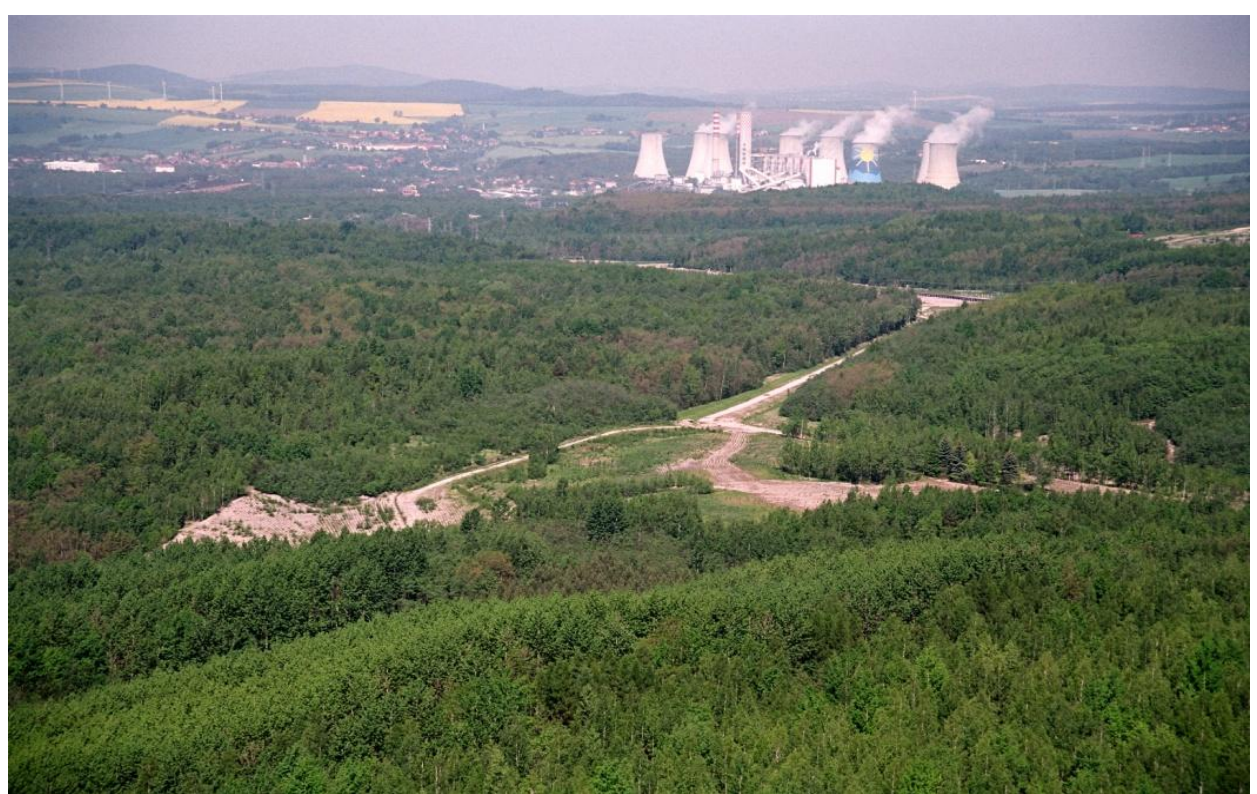

Fig. 3. View of the external dumping site of the Turów mine [phot. by the Turów mine]

\subsection{Municipal approach}

The above mentioned external dumping site of the Bełchatów mine, called Góra Kamieńsk, became a sports and recreational centre. On the northern slope of the dumping site there is a ski run with modern skiing facilities, hotels and food outlets, which is popular with winter sports fans. The surface area of the ski run together with the infrastructure amounts to $10 \mathrm{ha}$, and its length is over $800 \mathrm{~m}$. Thanks to a perfect location (6 $\mathrm{km}$ away form the Warsaw-Katowice dualcarriageway and $18 \mathrm{~km}$ from the town of Bełchatów), in winter the place is crowded with amateurs of winter sports. Apart from the ski run, there is also a $500 \mathrm{~m}$ long sleigh track and at the bottom of the hill there is a playground for children and teenagers with a go cart track, swings, etc). One should also mention the development idea of the Bełchatów post-mining land that has been prepared by the AGH University of Science and Technology and which assumes a further expansion of the recreational, sports and tourist infrastructure and the transformation of this area (when the lignite exploitation has been finished) into the biggest sports and recreation centre in Poland [4]. The plan includes such attractions as: a race track, an in-door ski run, a golf course, cycle paths, 


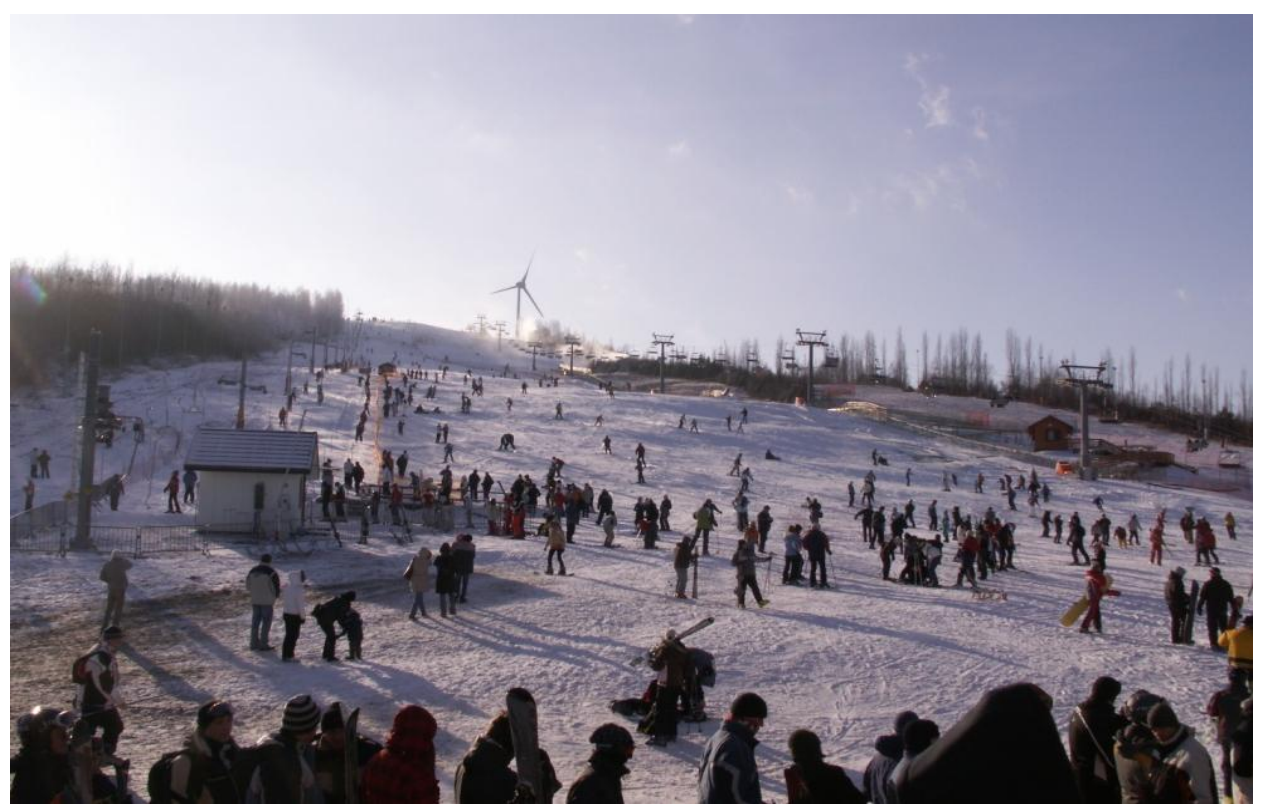

Fig. 4. A view on the ski run and sleigh track in Góra Kamieńsk in the Bełchatów mine [phot. by the Bełchatów lignite mine]

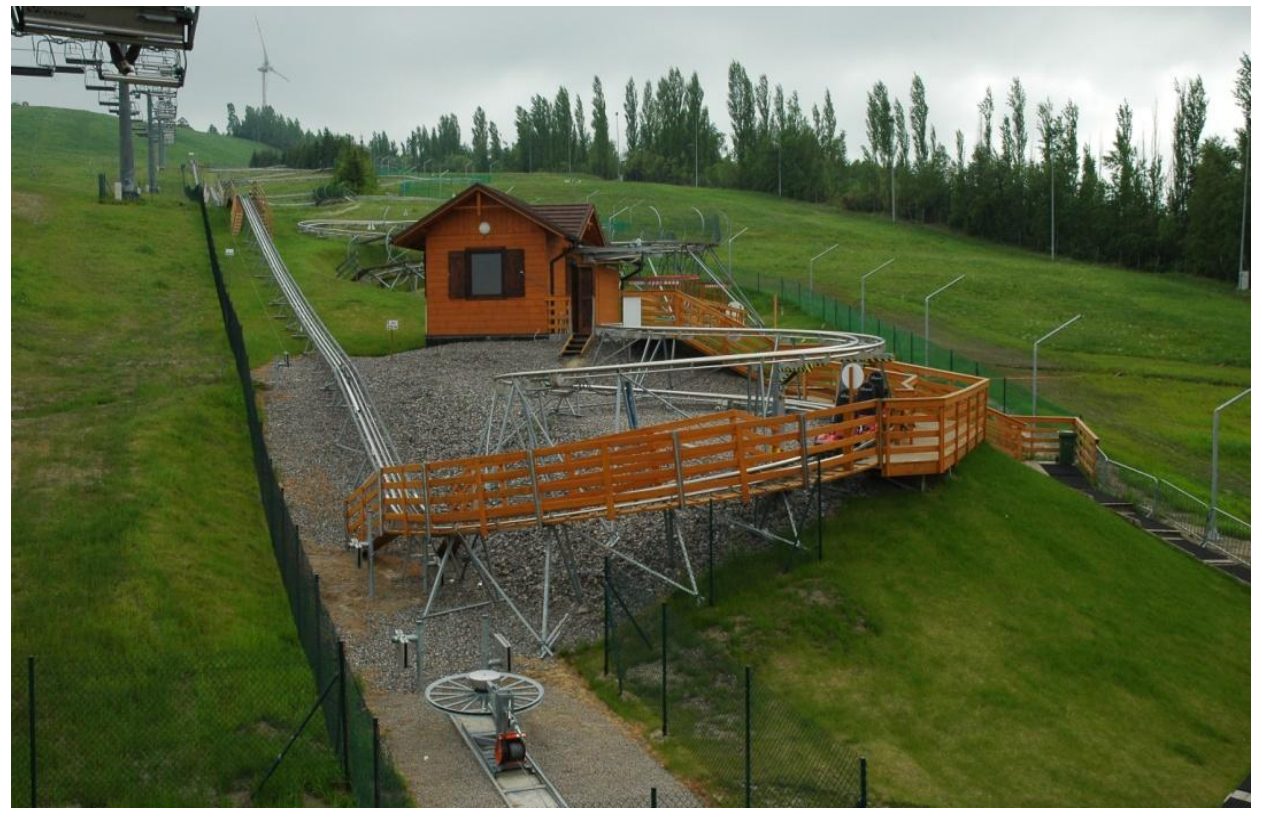

Fig. 5. A windmill farm with a ski run in the background in Góra Kamieńsk in the Bełchatów mine [phot. by Z. Kasztelewicz] 
technological park with excavators and dumping machines, a small motor and sailing boat harbour and, last but not least, two biggest lakes in central Poland with the surface of over 4000 ha.

\subsection{Hydrological approach}

Due to the single open-cast character of the exploitation the hydrological approach to reclamation in the Turów and Bełchatów mines consisted mainly in the creation of small water ponds in the external dumping sites. However, the situation is different in the case of the Adamów and Konin mines that have several open-casts. The former one constructed three medium-size reservoirs: Bogdałów, Przykona and Janiszew that serve the inhabitants as recreational sites in hot summers. The Konin lignite mine has the greatest experience in hydrological reclamation. So far 6 water reservoirs of the total area of 600 ha have been built. They are located in the former workings of the Niesłusz, Gosławice, Pątnów, Jóźwin IIA and Kazimierz Południe open-casts. The reservoir in the Pątnów open-cast is at present the biggest lake in the lignite mining with a surface of around 350 ha and a volume of almost $90 \mathrm{mln} \mathrm{m}$. In the reservoir in the Lubstów open-cast, where the exploitation finished in 2010, reclamation is being carried out aiming at the construction of the biggest postmining reservoir in Poland - bigger than the Machów reservoir - with the surface of over 480 ha and volume of almost $150 \mathrm{mln} \mathrm{m}^{3}$.

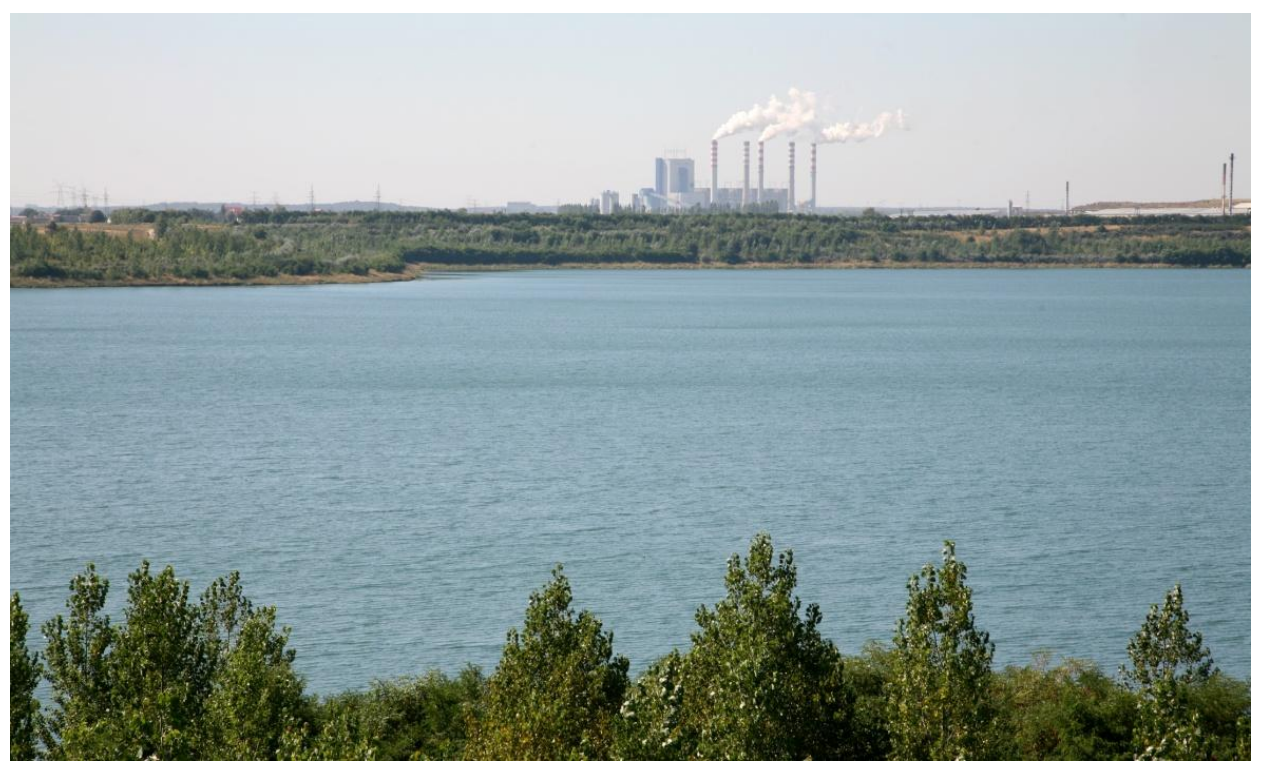

Fig. 6. The biggest water reservoir in the lignite mining sector on the site of the Pątnów open-cast in the Konin mine [phot. by Konin lignite mine] 


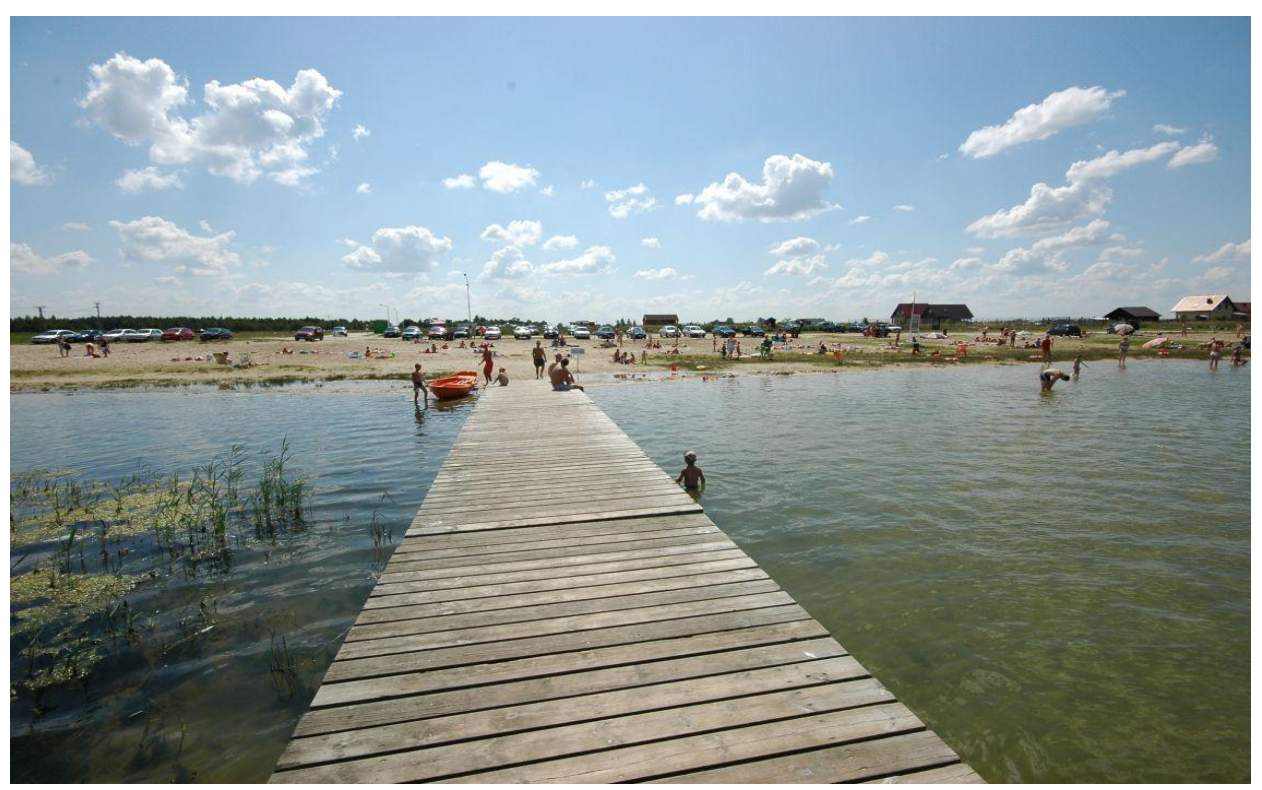

Fig. 7. Jetty on the Przykona water reservoir in the Adamów mine [phot. by Z. Kasztelewicz]

The above mentioned reservoirs are precious to local inhabitants as they provide a place to rest, create new jobs and increase the attractiveness of the neighbouring building lots.

\subsection{Special approach}

All other methods of the reclamation of post-mining land than the ones listed in 4.1-4.4 can be generally referred to as special approaches. The following directions of activities can be presented as examples of economic or cultural approaches [6]:

Table 5. Examples of special approaches to the reclamation of post-mining areas.

\begin{tabular}{|l|l|}
\hline \multirow{4}{*}{$\begin{array}{l}\text { Economic } \\
\text { approach }\end{array}$} & $\begin{array}{l}\text { household building, campuses, garages, tourist accommodation and } \\
\text { hotels }\end{array}$ \\
\cline { 2 - 2 } & $\begin{array}{l}\text { industrial parks } \\
\text { services: business incubators, warehouses, shops, car parks, sports } \\
\text { facilities, etc. }\end{array}$ \\
\cline { 2 - 2 } & waste dumps \\
\hline \multirow{4}{*}{$\begin{array}{l}\text { Cultural } \\
\text { approach }\end{array}$} & educational: theme paths, laboratories, conference and concert halls \\
\cline { 2 - 2 } & $\begin{array}{l}\text { meditative } \\
\text { artistic: museums, exhibitions, exhibition and concert halls, galleries, } \\
\text { theatres, cinemas, etc. }\end{array}$ \\
\hline
\end{tabular}


So far the Polish lignite mining industry has not followed the cultural approach, and the economic approach has been present in a limited way - one could mention here, for example, the windmill farm on the external dumping site of the Bełchatów mine or the construction of industrial and municipal waste dumping sites in the workings and dumping sites of particular lignite mines. Internal dumping sites (e.g. in the Bełchatów, Konin and Turów mines) are sometimes used to store ashes from power stations and as a result they are rendered harmless there. It seems that in the field of promotion and application of reclamation approaches other than traditional ones there is a lot to do in comparison to, for example, our western neighbours.

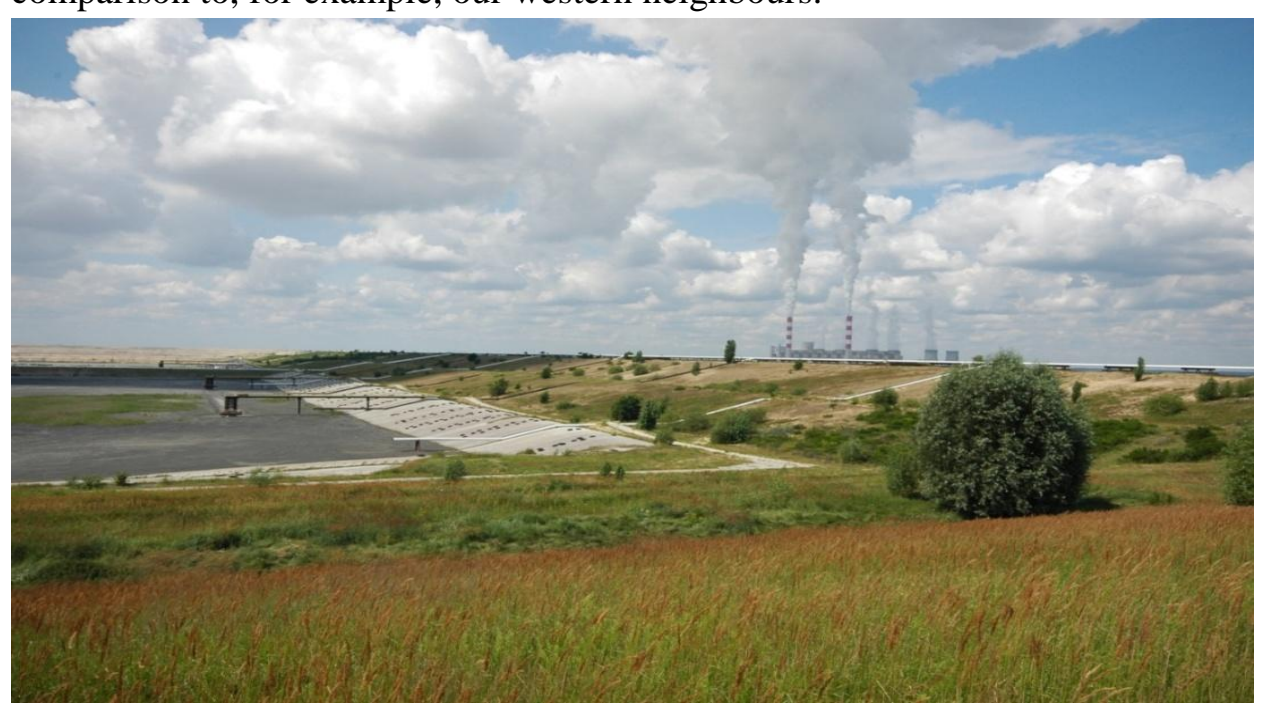

Fig. 8. Ash waste dump site for the Bełchatów Power station on the internal dumping site of the Bełchatów Field [phot. by Z. Kasztelewicz]

\section{SUMMARY}

Mining activities have always had an unfavourable image in society. This is due to previous decades when not enough attention was paid to the issues of reclamation and environmental protection. However, the negligence of the previous periods is systematically made up for. At the beginning of $21^{\text {st }}$ century very few examples of such past cases can be spotted.

The miners in the Polish open-cast mines regularly and in accordance to the mining art carry out the reclamation and development of land that is "regained" in time with the movement of the exploitation front. The work is done according to high European standard and as a result the land can be used by the agriculture or forest industry and by other activities, recreational one including. The mining 
consistently puts into practice the idea of the creator of sozology, the professor and rector of the AGH in Krakow, Walery Goetl that What man has destroyed, man must repair. Like plastic surgery, open-cast mining may be painful for the environment. However, if the exploitation is suitably, purposefully well planned and carried out, then the results may increase the attractiveness of the surrounding [5]. Open-cast exploitation may:

- add new morphological forms that are in harmony with the landscape,

- support environmental protection by the creation of new habitats,

- support forestry,

- create new places of recreation.

Numerous examples of the scenic, natural and cultural attractiveness of the postmining land make us look at mining as an activity that creates new environmental values and new conditions for environmental protection. The post-mining land with its unique scenery becomes a natural part of the region and it is not perceived as a place of previous exploitation.

\section{REFERENCES}

1. Kasztelewicz Z., Kaczorowski J.: Rekultywacja i rewitalizacja kopalń węgla brunatnego na przykładzie Kopalni Betchatów, VI Międzynarodowy Kongres Górnictwo Węgla Brunatnego. Kwartalnik AGH, seria: Górnictwo i Geoinżynieria, rok 33, zeszyt nr 2, Kraków 2009.

2. Kasztelewicz Z.: Rekultywacja terenów pogórniczych w polskich kopalniach odkrywkowych, Monografia. Nauka i Tradycje Górnicze, AGH Kraków 2010.

3. Kasztelewicz Z., Sypniowski S.: Kierunki rekultywacji $w$ polskich kopalniach wegla brunatnego na wybranych przyktadach, VII Międzynarodowy Kongres Górnictwo Węgla Brunatnego. Kwartalnik AGH, seria: Górnictwo i Geoinżynieria, rok 35, zeszyt nr 3, Kraków 2011.

4. Kasztelewicz Z., Szwed L.: Kierunki zagospodarowania terenów po likwidacji zakładów górniczych wydobywajacych węgiel brunatny, Przegląd Górniczy nr 11/2010.

5. Nieć M.: Górnictwo „Chirurgia plastyczna środowiska”, Praca niepublikowana. Instytut Gospodarki Surowcami Mineralnymi i Energią PAN, Kraków 2010.

6. Ostręga A.: Sposoby zagospodarowania wyrobisk i terenów po eksploatacji złóż surowców węglanowych na przykladzie Krzemionek Podgórskich w Krakowie, Rozprawa doktorska, Kraków 2004. 


\section{REKULTYWACJA TERENÓW POGÓRNICZYCH W POLSKIM GÓRNICTWIE ODKRYWKOWYM WĘGLA BRUNATNEGO}

\section{Streszczenie}

W artykule przedstawiono stan rekultywacji terenów pogórniczych w poszczególnych kopalniach węgla brunatnego w Polsce do $2012 \mathrm{r}$. na tle całego górnictwa odkrywkowego. Omówiono procesy nabywania terenów pod działalność górniczą i zbywania ich po przeprowadzonych pracach rekultywacyjnych oraz dotychczasowe osiagnnięcia kopalń w zakresie dokonanej rekultywacji i rewitalizacji terenów poeksploatacyjnych. Z artykułu wyłania się obraz byłych terenów eksploatacyjnych, które obecnie - po procesie zagospodarowania przeprowadzonego na europejskim poziomie - służą mieszkańcom do celów rekreacyjnych i w sposób znaczący podnoszą atrakcyjność regionów, w których się znajdują.

Słowa kluczowe: kopalnie odkrywkowe weggla brunatnego, zagospodarowanie terenu, rewitalizacja, rekultywacja

Editor received the manuscript: $\quad$ 08.04.2013 